\title{
PENGARUH MENGKONSUMSI MAKANAN MANIS DAN LENGKET TERHADAP PH SALIVA PADA MURID SDN MAMAJANG MAKASSAR
}

\author{
Asridiana, Ernie Thioritz
}

\begin{abstract}
ABSTRAK
Makanan manis dengan konsistensi lengket sulit dibersihkan dari permukaan gigi dan merupakan yang mudah difermentasikan bakteri yang dapat melarutkan struktur gigi dan memicu terjadinya karies. Walaupun cairan saliva merupakan pembersih alamiah rongga mulut, namun perlekatan makanan manis dan lengket sulit dibersihkan terutama pada fissure dan cela gigi. Pola makan anak-anak yang mempunyai kecenderungan untuk memakan makanan kariogenik, serta kurangnya kesadaran dan kedisiplinan dalam pemeliharaan kebersihan gigi dan mulut menyebabkan status kebersihan gigi dan mulut buruk sehingga prevalensi kariesnya tinggi ( Alhamda 2011).Tujuan penelitian ini adalah untuk menganalisis pengaruh mengkonsumsi makanan lengket dan manis terhadap $\mathrm{pH}$ saliva. Hasil penelitian pH sebelum makan 6,04, 5 menit setelah makan 5,73, 15 setelah makan 5,62, 30 menit setelah makan 5,21. Dari hasil uji statistik dengan uji Anova ada pengaruh mengkomsumsi makanan manis dan lengket terhadap $\mathrm{pH}$ saliva pada murid sdn Mamajang 2 makassar, baik pada 5 menit setelah makan, 15 menit dan 30 menit.
\end{abstract}

Kata Kunci: Makanan Manis dan lengket, pH saliva.

\section{PENDAHULUAN}

Penyakit gigi dan mulut sangat terhadap perkembangan kesehatan gigi pada usia mempengaruhi derajat kesehatan, proses tumbuh kembang, bahkan masa depan anak. Anak-anak menjadi rawan kekurangan gizi karena rasa sakit pada gigi dan mulut menurunkan selera makan mereka. Kemampuan belajar anak pun akan menurun sehingga akan berpengaruh pada prestasi belajar (Zatnika, 2009)

Di Indonesia telah terjadi perubahan pola makan akibat dari meningkatnya penggunaan refined carbohydrat atau dalam kehidupan sehari-hari dikenal sebagai kembang gula ,coklat dan penganan lain yang banyak mengandung sukrosa.Jenis makanan tersebut banyak di komsumsi oleh anak-anak. Makanan tersebut umumnya mudah melekat pada permukaan gigi.Bila anak malas untuk membersihkan giginya, maka sisa makanan tersebut akan diubah menjadi asam oleh bakteri yang terdapat dalam mulut, kemudian dapat terjadinya karies gigi.( Anonimous, 2019)

Upaya pemeliharaan dan pembinaan kesehatan gigi dan mulut terutama pada kelompok usia sekolah perlu mendapat perhatian khusus sebab pada usia ini anak sedang menjalani proses tumbuh kembang.Keadaan gigi sebelumnya akan berpengaruh dewasa nanti. Bila ditinjau dari berbagai upaya pencegahan karies gigi melalui kegiatan Usaha Kesehatan Gigi Sekolah seharusnya pada anak usia sekolah dasar memiliki angka karies rendah. Penelitian Sutiawati menunjukkan adanya tingkat karies yang cukup tinggi pada anak sekolah.( Alhamda, 2011)

The American Dental Association (ADA) merekomendasikan untuk menyikat gigi 2 kali sehari dan menggunakan benang gigi atau pembersih interdental lainnya sekali sehari untuk menghilangkan plak dan mencegah gingivitis.Walaupun demikian, tindakan pengendalian plak secara mekanis dianggap tidak cukup potensial dalam mencegah pembentukan plak. Hal ini berdasarkan fakta bahwa beberapa bagian tertentu dari kavitas rongga mulut sulit dibersihkan secara efektif dengan alat mekanis.

Berdasarkan laporan sebelumnya dikatakan bahwa rata-rata tindakan menyikat gigi yang dilakukan sehari-sehari selama dua menit hanya menyingkirkan $50 \%$ plak dalam rongga mulut. Beberapa penelitian juga menunjukkan bahwa kebanyakan pasienmenyikat gigi kurang dari waktu rata-rata yang dianjurkan untuk mendapatkan hasil pembersihan yang tepat dan hanya 
$2-10 \%$ pasien yang menggunakan benang gigi secara rutin dan efektif. (Oktarianda, 2011)

Derajat keasaman $(\mathrm{pH})$ saliva merupakan salah satu faktor penting yang berperan dalam karies gigi,kelainan periodontal dan penyakit lain dirongga mulut.Kadar derajat keasaman $(\mathrm{PH})$ saliva yang normal didalam mulut berada diangka 7 dan bila nilai $\mathrm{PH}$ saliva jatuh $\leq 5,5$ berarti keadaannya sudah sangat kritis. Nilai pH saliva berbanding terbalik, dimana makin rendah nilai $\mathrm{pH}$ makin banyak asam dalam larutan ,sebaliknya makin meningkatnya nilai $\mathrm{pH}$ berarti bertambahnya basa dalam larutan. Derajat keasaman $(\mathrm{pH})$ saliva merupakan bagian yang terpenting dalam meningkatkan integritas gigi karena dapat meningkatkan terjadinya remineralisasi ,dimana penurunan $\mathrm{pH}$ dapat menyebabkan demineralisasi gigi. Adanya proses remineralisasi yang menurunkan menurunkan terjadinya karies. (Alamsyah, 2010)

SD Negeri Mamajang merupakan salah satu sekolah yang lokasinya berada tidak jauh dari kampus jurusan keperawatan gigi, sehingga memudahkan penulis untuk melakukan penelitian disekolah tersebut. Disamping itu di wilayah ini banyak terdapat tempat berjualan berbagai jenis jajanan, sehingga memudahkan siswa untuk jajan. Berdasarkan observasi pendahuluan yang dilakukan peneliti didapati bahwa siswa SD tersebut jarang membawa bekal makanan dari rumah dan banyak yang membeli jajanan saat istirahat.

SD Negeri Manajemen II merupakan SD binaan puskesmas Mamajang dengan 2 puskesmas pembantu (PUSTU) yaitu PUSTU Mamajang Dalam dan PUSTU Maricaya Selatan .Pada SD Negeri Mamajang II program UKGS nya belum berjalan aktif melakukan pemeriksaan gigi dan mulut secara berkala. Dimana setelah kami melakukan survei awal ke SD
Negeri Mamajang II tersebut didapatkan kriteria karies gigi tergolong kategori sedang DMF-T(3,0).

Dengan demikian kami tertarik untuk melakukan kegiatan pengabdian masyarakat pada SD Negeri Mamajang II untuk mencegah terjadinya karies gigi melalui pemberian pit dan fissure sealant, sesuai standar WHO untuk nilai karies gigi dan mulut (DMF-T) adalah 0,0-1,1 (kategori sangat rendah), 1,2 -2,6 (kategori rendah), 2,7-4,4 (kategori sedang), 4,5-6,5 (kategori tinggi), 6,6>(kategori sangat tinggi)

Sayuti (2010) menyatakan bahwa adanya pengaruh makanan manis dan lengket terhadap terjadinya karies gigi pada anak-anak. Makanan manis dan lengket yang digunakan pada penelitian ini adalah coklat,karena termasuk jenis makanan manis danlengket serta lebih lunak dibandingkan dengan permen ,biskuit, roti,dan wafer. Menurut penelitian Diana (2004), semakin besar kekuatan mastikasi maka semakin besar saliva yang dihasilkan. Salah satu faktor yang mempengaruhi gerakan mastikasi yaitu konsistensi makanan. Saat mengkomsumsi makanan dengan konsistensi cair (lunak) organ mastikasi kurang menjalankan fungsi pengunyahan. Namun sebaliknya, saat mengkomsumsi makanan dengan konsistens padat (keras) organ mastikasi bekerja sangat keras.

\section{HASIL PENELITIAN DAN PEMBAHASAN}

\section{Hasil Penelitian}

Penelitian mengenai pengaruh mengkonsumsi makanan manis dan lengket terhadap $\mathrm{pH}$ saliva pada murid SDN Mamajang II Makassar telah dilakukan.Penelitian ini merupakan penelitian eksperimental semu dan menggunakan rancangan penelitian cross- sectional.

Tabel 1. Distribusi Rata-Rata pH Saliva Sebelum Makan Makanan Manis dan Lengket Berdasarkan Jenis Kelamin

\begin{tabular}{|c|c|c|c|}
\hline No. & Jenis Kelamin & Jumlah individu & PH rata-rata \\
\hline 1. & $\mathrm{P}$ & 22 orang & 6,08 \\
\hline 2. & $\mathrm{~L}$ & 18 orang & 5,98 \\
\hline
\end{tabular}


Berdasarkan tabel 1 diketahui bahwa jumlah sampel perempuan 22 orang dengan $\mathrm{pH}$ rata-rata sebelum mengkonsumsi makanan manis dan lengket adalah
6.08 sedang jumlah sampel laki-laki 18 orang dengan rata-rata $\mathrm{pH}$ sebelum mengkonsumsi makanan manis dan lengket adalah 5,98

Tabel 2. Distribusi Rata-Rata pH Sebelum Makan dan pH 5 Menit Setelah Makan, 15 Menit Setelah Makan dan 30 Menit Setelah Makan

\begin{tabular}{|c|c|c|c|}
\hline pH sebelum makan & $\begin{array}{c}\text { PH 5 menit setelah } \\
\text { makan }\end{array}$ & $\begin{array}{c}\text { pH15 menit setelah } \\
\text { makan }\end{array}$ & $\begin{array}{c}\text { PH 30 menit setelah } \\
\text { makan }\end{array}$ \\
\hline 6,04 & 5,73 & 5,62 & 5,21 \\
\hline
\end{tabular}

Berdasarkan tabel 2 rata-rata $\mathrm{pH}$ saliva sebelum makan makanan manis dan lengket adalah 6,04, kemudian setelah 5 menit makan makanan manis dan lengket $\mathrm{pH}$ saliva 5,73 dan 15 menit setelah konsumsi makanan manis dan lengket $\mathrm{pH}$ saliva 5,62 serta 30 menit setelah konsumsi makanan manis dan lengket $\mathrm{pH}$ saliva 5,21

Tabel 3. Distribusi Rata-Rata pHSaliva Sebelum Konsumsi Makanan Manis dan Rata-Rata pH Saliva 5,15,30 Menit Setelah Konsumsi Makanan Manis dan Lengket Berdasarkan Jenis Kelamin

\begin{tabular}{|c|c|c|c|}
\hline Jenis kelamin & $\begin{array}{c}5 \text { menit setelah } \\
\text { makan }\end{array}$ & $\begin{array}{c}15 \text { menit setelah } \\
\text { makan }\end{array}$ & $\begin{array}{c}30 \text { menit setelah } \\
\text { makan }\end{array}$ \\
\hline $\mathrm{P}$ & 4,7 & 4,55 & 4,25 \\
\hline $\mathrm{L}$ & 7,21 & 6,92 & 6,38 \\
\hline
\end{tabular}

Berdasarkan tabel 3 diketahui bahwa ratarata $\mathrm{pH}$ saliva pada laki2 setelah 5 menit makan makanan manis adalah 7,21 , setelah 15 menit 6,92 dan setelah 30 menit 6,38 dan rata-rata $\mathrm{pH}$ saliva pada perempuan setelah 5 menit konsumsi makanan manis dan lengket adalah 4,7 , setelah 15 menit 4,55 dan setelah 30 menit 4,25

Tabel 4. Pengaruh Mengkonsumsi Makanan Manis dan Lengket Terhadap pH Saliva Pada Murid SDN Mamajang Makassar Setelah 5 Menit

\begin{tabular}{|c|c|c|}
\hline $\begin{array}{c}\mathrm{pH} \text { Sebelum Mengkonsumsi } \\
\text { Makanan Manis dan Lengket }\end{array}$ & $\begin{array}{c}\mathrm{pH} 5 \text { Menit Setelah Mengkonsumsi } \\
\text { Makanan Manis dan Lengket }\end{array}$ & $\mathrm{P}$ - value \\
\hline 6,04 & 5,73 & 0,00 \\
\hline
\end{tabular}

Uji Anova : $p<0,05=$ significant

Berdasarkan uji korelasi menggunakan uji Paired T- test seperti yang ditunjukkan pada table 4, pengaruh mengkonsumsi makanan manis dan lengket setelah 5 menit di SDN Mamajang Makassar diperoleh nilai $p \leq 0,05$ yang menunjukkan bahwa terdapat pengaruh antara mengkonsumsi makanan manis dan lengket terhadap $\mathrm{pH}$ saliva pada siswa SDN Mamajang Makassar. 
Tabel 5. Pengaruh Mengkonsumsi Makanan Manis dan Lengket Terhadap pH Saliva Pada Murid SDN Mamajang Makassar Setelah 15 menit

\begin{tabular}{|c|c|c|}
\hline $\begin{array}{c}\text { PH Sebelum Mengkonsumsi } \\
\text { Makanan Manis dan Lengket }\end{array}$ & $\begin{array}{l}\text { 15 Menit Setelah Mengkonsumsi } \\
\text { Makanan Manis dan Lengket }\end{array}$ & $\mathrm{P}-$ value \\
\hline 6,04 & 5,62 & 0,00 \\
\hline
\end{tabular}

Berdasarkan uji korelasi menggunakan uji Anova seperti yang ditunjukkan pada table 4, pengaruh mengkonsumsi makanan manis dan lengket setelah 15 menit di SDN Mamajang Makassar diperoleh nilai $p \leq 0,05$ yang menunjukkan bahwa terdapat pengaruh antara mengkonsumsi makanan manis dan lengket terhadap pH saliva pada siswa SDN Mamajang Makassar.

Tabel 6. Pengaruh Mengkonsumsi Makanan Manis Dan Lengket Terhadap pH Saliva Pada Murid SDN Mamajang Makassar Setelah 30 Menit

\begin{tabular}{|c|c|c|}
\hline $\begin{array}{c}\text { PH sebelum mengkonsumsi } \\
\text { makanan manis dan lengket }\end{array}$ & $\begin{array}{c}30 \text { menit setelah mengkonsumsi } \\
\text { makanan manis dan lengket }\end{array}$ & P - value \\
\hline 6,04 & 5,21 & 0,00 \\
\hline
\end{tabular}

Berdasarkan uji korelasi menggunakan uji Anova seperti yang ditunjukkan pada table 4, pengaruh mengkonsumsi makanan manis dan lengket setelah 30 menit di SDN Mamajang Makassar diperoleh nilai $p \leq 0,05$ yang menunjukkan bahwa terdapat pengaruh antara mengkonsumsi makanan manis dan lengket terhadap $\mathrm{pH}$ saliva pada siswa SDN Mamajang Makassar.

\section{PEMBAHASAN}

Penelitian mengenai pengaruh mengkonsumsi makanan manis dan lengket terhadap $\mathrm{pH}$ saliva pada murid SDN Mamajang II Makassar. Pengambilan sampel dilakukan dengan menggunakan metode purposive sampling. Total responden yang mengikuti penelitian ini adalah 40 orang, dengan jumlah responden laki-laki 22 orang dan perempuan 18 orang.

Pada penelitian ini kami menggunakan makanan manis dan lengket adalah coklat karena termasuk jenis makanan yang lunak dibanding biscuit dan roti. Seperti diketahui bahwa makanan maupun minuman ringan menjadi kegemaran anak- anak mengandung sejumlah besar gula yang bila dikonsumsi terlalu sering akan menyebabkan karies. Hal ini sependapat dengan Wieke dan Susy (2008) yang menyatakan bahwa rasa manis merupakan rasa yang paling disukai kebanyakan orang terutama anak-anak.Sumber rasa manis ini dapat diperoleh dari sukrosa yang dikonsumsi dalam bentuk gula dan sering digunakan untuk makanan dan minuman terutama minuman ringan.(Suyuti, 2010)

Saliva adalah cairan oral yang kompleks yang terdiri atas campuran sekresi dari kelenjar saliva mayor dan minor yang ada pada rongga mulut. Saliva sebagian besar yaitu sekitar 90 persennya dihasilkan saat makan yang merupakan reaksi atas rangsangan yang berupa pengecapan dan pengunyahan makanan. Saliva yang terbentuk di rongga mulut, sekitar $90 \%$ dihasilkan oleh kelenjar submaxiller dan kelenjar parotis, $5 \%$ oleh kelenjar sublingual, dan $5 \%$ lagi oleh kelenjar-kelenjar saliva kecil.

Setelah makan khususnya makanan karbohidrat, akan terjadi fermentasi terhadap 
glukosa makanan. Hasilnya berupa senyawa bersifat asam dan membuat lingkungan sekitar gigi bersuasana asam. Dalam beberapa menit derajat keasaman tadi akan meningkat atau $\mathrm{pH}$ - nya akan turun. Bila berlanjut, penurunan nilai $\mathrm{pH}$ akan sampai ke nilai kritis, yaitu nilai $\mathrm{pH}$ yang akan memicu dekalsifikasi (hilangnya garam kalsium) pada email gigi. Keberadaan perubahan suasana $\mathrm{pH}$ setelah makan ini akan kembali normal setelah 20 - 30 menit kemudian. Selama 5 - 10 menit pertama setelah makan adalah saat-saat kritis $\mathrm{pH} 9$ (sekitar 5,2- 5,5) (Oktarianda, 2011)

Pada penelitian ini, diperoleh bahwa nilai $\mathrm{pH}$ saliva sebelum mengkonsumsi makanan manis dan lengket 6,04 dengan kriteria agak asam dan setelah 5 menit mengkonsumsi makanan manis dan lengket nilai $\mathrm{pH}$ saliva menurun sebesar $5,73,15$ menit setelah mengkonsumsi makanan manis dan lengket nilai $\mathrm{pH}$ saliva semakin menurun sebesar 5,62 dan 30 menit setelah mengkonsumsi makanan manis dan lengket pH saliva 5,21.

Saliva mempengaruhi proses terjadinya karies karena saliva selalu membasahi gigi geligi sehingga mempengaruhi lingkungan dalam rongga mulut. Derajat keasaman $(\mathrm{pH})$ saliva merupakan salah satu faktor penting yang berperan dalam karies gigi, kelainan periodontal, dan penyakit lain di rongga mulut berada di angka 7 dan bila nilai $\mathrm{pH}$ saliva jatuh $\leq 5,5$ berarti keadaan sudah sangat kritis. Nilai $\mathrm{pH}$ saliva berbanding terbalik, di mana makin rendah nilai $\mathrm{pH}$ makin banyak asam dalam larutan. Sebaliknya makin meningkatnya nilai $\mathrm{pH}$ berarti bertambahnya basa dalam larutan. Pada $\mathrm{pH}$ 7, tidak ada keasaman atau kebasaan larutan dan ini disebut netral. Pertumbuhan bakteri terjadi pada $\mathrm{pH}$ saliva yangoptimum berkisar 6,5-7,5 dan bila rongga mulut $\mathrm{pH}$ salivanya rendah $(4,5-5,5)$ akan memudahkan pertumbuhan kuman asidogenik seperti Streptococcus mutans dan Lactobacillus. Derajat keasaman $(\mathrm{pH})$ saliva merupakan bagian yang penting dalam meningkatkan integritas gigi karena dsapat meningkatkan terhjadinya remineralisasi, dimana penurunan $\mathrm{pH}$ saliva dapat menyebabkan demineralisasi gigi. Adanya proses remineralisasi yang akan menurunkan kemungkinan terjadinya karies. Remineralisasi adalah suatu proses dimana permukaan gigi akan memperoleh mineral kembali.

Pada penelitian ini, diperoleh bahwa sebelum mengkonsumsi makanan manis dan lengkat memiliki rata-rata $\mathrm{pH}$ saliva 6,04 agak asam.Hal ini dikarenakan karena konsentrasi bikarbonat pada saliva istirahat bersifat rendah, sehingga suplay bikarbonat pada kapasitas buffer saliva paling tinggi hanya mencapai $50 \%$, sedangkan pada saliva yang dirangsang dapat menyuplai sampai $85 \%$.

Studi menunjukkan bahwa beberapa factor yang menyebabkan terjadinya perubahan pada $\mathrm{pH}$ saliva antara lain rata-rata kecepatan aliran saliva, mikroorganisme rongga mulut, dan kapasitas buffer saliva. Selain itu ada factor - factor yang mempengaruhi pembentukan asam antara lain: jenis karbohidrat yang terdapat dalam diet, konsentrasi karbohidrat dalam diet, jenis dan jumlah bakteri di dalam plak, keadaan fisiologis bakteri tersebut dan pH di dalam plak.( Rahmawati,2011)

Sedangkan pada kelompok sesudah makan makanan manis dan lengket rata- rata $\mathrm{pH}$ saliva lebih asam. Hal ini dikarenakan kondisi mulut saat makan lebih asam dibandingkan dengan kelompok sebelum makan makanan manis dan lengket. Kemampuan bakteri memetabolisme makanan menjadi asam lebih besar dibanding sebelum makan karena kondisi lingkungan yang mendukung dan total bakteri di rongga mulut jauh lebih banyak.

Hal ini sejalan dengan penelitian yang dilakukan oleh Tecky Indriana ,2011 yang menunjukkan terdapat perbedaan yang signifikan laju aliran saliva dan $\mathrm{pH}$ antara saliva tanpa stimulasi dan saliva terstimulasi (kimiawi dan mekanis). Derajat keasaman $(\mathrm{pH})$ saliva sangatlah bervariasi antara individu satu dengan individu yang lainnya.Pada diet yang mengandung karbohidrat akan menyebabkan turunnya $\mathrm{pH}$ saliva yang dapat mempercepat terjadinya demineralisasi enamel gigi. Sepuluh menit setelah makan karbohidrat akan 
dihasilkan asam melalui proses glikolisis dan $\mathrm{pH}$ dapat menurun sampai dibawah $\mathrm{pH}$ kritis. Intake makanan yang mengandung asam terbukti menurunkan level $\mathrm{pH}$. Saat nilai $\mathrm{pH}$ turun, mukoprotein akan didenaturasi, dan fungsi lubrikasi hilang karena tidak adanya asam sialin.

Berdasarkan hasil uji korelasi menggunakan uji Paired t test menunjukkan bahwa pengaruh mengkonsumsi makanan manis dan lengket terhadap $\mathrm{pH}$ saliva pada murid SDN Mamajang Makassar diperoleh nilai $p \leq 0,05$ yang menunjukkan bahwa terdapat pengaruh yang signifikan antara mengkonsumsi makanan manis dan lengket terhadap $\mathrm{pH}$ saliva pada murid SDN Mamajang Makassar. Hasil ini sejalan dengan penelitian yang dilakukan oleh Shandy Hidayat, 2014 yang menunjukkan bahwa terdapat perbedaan $\mathrm{pH}$ saliva menggosok gigi sebelum dan sesudah mengonsumsi makanan manis dan lengket yang diukur menggunakan $\mathrm{pH}$ meter pada anak usia 1012 tahun di SDN Melayu 2 Banjarmasin Studi menunjukkan bahwa makanan manis dan lengket mengandung karbohidrat yang merupakan sumber energy utama bagi bakteri mulut dan secara lansung terlibat dalam penurunan $\mathrm{pH}$. Jenis karbohidrat yang paling cocok bagi produksi asam oleh bakteri $\mathrm{di}$ dalam plak adalah gula-gula sederhana, seperti sukrosa, glukosa, fruktosa, maltose, dan lain-lain. Gula-gula ini mempunyai molekul yang kecil sehingga mudah berdifusi ke dalam plak dan dengan cepat akan dipecah oleh bakteri menjadi asam. Karbohidrat jenis polisakarida (pati) mempunyai molekul lebih besar akan sulit dipecah oleh bakteri (Warni L, 2009).

Berdasarkan hasil penelitian tentang ratarata $\mathrm{pH}$ saliva berdasarkan jenis kelamin menunjukkan bahwa tidak ada perbedaan. Hal ini dikarenakan berdasarkan jenis kelamin tidak terlalu memiliki perbedaan yang jauh, baik dari tingkah laku maupun pengetahuan.Secara anatomi, muskulusskeletal cranium laki-laki dan perempuan tidak terdapat perbedaan yang signifikan. Sistem mastikasi sangat berpengaruh dengan produksi saliva. Menurut penelitian Diana (2004), semakin besar kekuatan mastikasi maka semakin besar saliva yang dihasilkan (Ningsih, 2004) Hal ini sesuai penelitian yang dilakukan oleh Motoc dkk (2003) bahwa tidak ada perbedaan rata-rata $\mathrm{pH}$ saliva berdasarkan umur dan jenis kelamin. $\mathrm{PH}$ saliva dapat dipengaruhi oleh aliran saliva dan diet. (Motoc, 2003)

\section{SIMPULAN DAN SARAN}

\section{Simpulan}

Berdasarkan hasil penelitian yang telah diperoleh, maka dapat disimpulkan beberapa hal sebagai berikut:

1. Ada pengaruh mengkonsumsi makanan manis dan lengket terhadap $\mathrm{pH}$ saliva pada murid SDN Mamajang Makassar

2. Dari hasil uji statistik antara mengkonsumsi makanan manis dan lengket terhadap $\mathrm{pH}$ saliva adalah signifikan

\section{Saran}

1. Agar pelaksanaan UKGS disekolah dapat merubah pola jajan murid SD dan disarankan menggosok gigi sesudah mengkonsumsi makanan manis dan lengket.

2. diharapkan pada peneliti selanjutnya dapat mengkaji lebih lanjut perubahan $\mathrm{pH}$ saliva dengan variable yang berbeda.

\section{DAFTAR PUSTAKA}

1. Alhamda. 2011. Pencegahan primer pada oral yang beresiko harus tinggi. Majalah ked yang (dent J)

2. Asadoorian J. CDHA : Position paper on tooth brushing. CJDH 2006; 40(5): 232-48.

3. Anoniomous. Laporan hasil riset kesehatan dasar RISKESDAS provinsi Kalimantan Selatan 2007. Jakarta Departemen Keseahatan RI; 2009. P116-(7)

4. Angela,A. Pencegahan primer pada anak yang beresiko karies tinggi. Majalah kedokteran gigi Dent.J ), 38( 3 ), pp. $130-134$

5. Asadoorian J . CDHA : Position paper on tooth brushing. CJDH 2006; 40(5): 232-48.

6. Alamsyah RM Efek perbedaan cara meminum softdrink terhadap penurunan $\mathrm{pH}$ saliva pada siswa SMP Raksana Medan,2010 pp 2-9

7. Boyle P, Koechlin A, Autier P. Mouthwash use and the prevention of plaque, gingivitis and 
caries. Oral Head and Neck Disease 2014; 20(suppl.1): 1-3.

8. Barnes VM, Arvanitidou E, Szewczyk G, Richter R, DeVizio W, Cronin M, et al. Evaluation of the antiplaque efficacy of two cetylpyridinium chloride-containing mouthwashes. J Clin Dent 2011; 22 [Spec Iss] 200-3.

9. Haake SK, Newman MG, Nisengard RJ, Sanz M. Periodontal microbiology. In: Newman MG, Takei HH, Carranza FA, eds. Clinical Periodontology. 9th ed., PHiladelpHia: WB Saunders, 2002: 97-8.

10. Hujoel P. Fundamental in the methods of periodontal disease epidemiology. In: Newman MG, Takei HH, Klokkevold PR, Carranza FA, eds. Carranza's Clinical Periodontology. 11th ed., St. Louis: Elsevier, 2012: 61, 452-60.

11. Hidayat, shandy, dkk. 2014 perbedaan $\mathrm{PH}$ saliva mengosok gigi sebelum dan sesudah mengkomsumsi makanan manis dan lengket. VOL II NO I

12. Ningsih $\overline{D S}$ Pengaruh mastikasi terhadap kecepatan aliran saliva, Medan; FKG Universitas Sumatera Utara; 2004 P 12, 29

13. Motor M, Samoila C, Strijan F, Ardelean L, Vordes D, Andreim, Andrei $M$, Anghel $M$ Popescu A. The variation of some salivary components in correlation with, sex and age at puberty TMJ 2003, 53:3 (4) 255

14. Oktarianda B Hub waktu, teknik menggosok gigi dan jenis makanan yang dikonsumsi dengan kejadian karies gigi pada murid SDN 66 Payakumbuh di wilayah kerja Puskesmas Lampasi Payakumbuh.Tahun 2011. Padang FK Universitas Andalas, 2011 P4

15. Rahmayanti, 2013 peran makanan terhadap kejadian karies gigi. Kesmas Jurnal. Padang: Universitas Andalas ( Online)

16. Sriyono, N, 2009, Pengantar ilmu Ked yang pencegahan cetakan ketiga, Yogyakarta: Medika Fakultas IImu Ked UGM.

17. Suyuti M Pengaruh makanan manis dan lengket terhadap terjadinya karies gigi pada anak usia 9 - 10 tahun di SD Negeri Monginsidi II Makassar. Media Kesehatan Gigi 2010; 2: 14

18. Warni L,2009 Hubungan perilaku murid SD kelas $\mathrm{V}$ dan $\mathrm{VI}$ pada kesehatan gigi dan mulut terhadap status karies gigi di wilayah kecamatan Delitua, kabupaten Dili serdang Medan FKM Universitas Sumatera Utara p 29

19. Rao D, Arvanitidou E, Du-Thumm L, Rickard AH. Efficacy of an alkohol-free CPC-containing mouthwash against oral multispecies biofilms. J Clin Dent 2011; 22 [Spec Iss]: 187-94. 